\title{
Perbandingan Konsentrasi IgE Air Mata Penderita Alergi Okuli dengan Pemberian Pemirolast Potassium 0,1\% dan Sodium Cromoglycate 4\%
}

\section{Comparison of IgE Concentration in the Tears of the Ocular Allergic Patients between the Treatment of Pemirolast Potassium 0,1\% and Sodium Cromoglycate 4\%}

\author{
Hariwati Moehariadi, Yasmine \\ Laboratorium IImu Kesehatan Mata Rumah Sakit Umum Dr. Saiful Anwar Malang
}

\begin{abstract}
ABSTRAK
Penyakit alergi okuli adalah penyakit alergi pada konjungtiva atau kulit kelopak mata, berhubungan dengan reaksi inflamasi karena menempelnya immunoglobulin E (IgE) di sel mast. Penatalaksanaan penyakit alergi okuli meliputi meminimalkan kontak dengan alergen dan pemberian obat-obatan (antihistamin, stabilisator sel mast (sodium cromoglycate, pemirolast potassium, lodoxamide, nedocromil sodium), kombinasi antihistamin dan stabilisator sel mast (kortikosteroid, siklosporin). Tujuan penelitian ini adalah untuk mengetahui penurunan konsentrasi IgE dan perbedaan penurunan konsentrasi IgE penderita alergi okuli sesudah diterapi dengan pemirolast potassium 0,1\% atau sodium cromoglycate 4\%.Penelitian ini merupakan pre and post clinical trial design pada 32 penderita alergi okuli. Sebanyak 16 penderita mendapatkan tetes mata pemirolast potassium $0,1 \%$ dan 16 lainnya mendapatkan tetes mata sodium cromoglycate $4 \%$. Air mata penderita diambil saat datang dan satu minggu setelah terapi untuk pemeriksaan konsentrasi IgE dan diperiksa menggunakan ELISA reader. Penurunan konsentrasi IgE sebelum dan setelah terapi pada masing-masing obat diuji menggunakan uji T-test dependent, sedangkan perbandingan penurunan konsentrasi IgE antara kedua obat diuji menggunakan uji T-test independent. Pada kelompok pemirolast potassium 0,1\%, konsentrasi IgE awal 730,73 \pm SD 40,17 $\mathrm{IU} / \mathrm{ml}$ dan menurun menjadi $678,61 \pm \mathrm{SD} 56,20 \mathrm{IU} / \mathrm{ml}$. Kelompok sodium cromoglycate $4 \%$, konsentrasi IgE awal 731,16 \pm SD $32,13 \mathrm{lU} / \mathrm{ml}$ dan menurun menjadi $686,73 \pm \mathrm{SD} 43,08 \mathrm{IU} / \mathrm{ml}(\mathrm{p}=0,000)$. Perbedaan penurunan konsentrasi IgE pada kelompok pemirolast potassium $0,1 \%$ sebesar $52,12 \pm$ SD $41,00 \mathrm{IU} / \mathrm{ml}$, kelompok sodium cromoglycate $4 \%$ sebesar $44,43 \pm$ SD 32,63 IU/ml. Perbedaan penurunan konsentrasi IgE antara kedua obat tidak bermakna $(p=0,561)$. Dapat disimpulkan tidak didapatkan perbedaan bermakna efek pemirolast potassium $0,1 \%$ dan sodium cromoglycate $4 \%$ dalam menurunkan konsentrasi IgE air mata penderita alergi okuli.
\end{abstract}

Kata Kunci: Konsentrasi IgE, penyakit alergi okuli, pemirolast potassium 0,1\%, sodium cromoglycate $4 \%$

\begin{abstract}
Ocular allergy disease is allergic disease in conjunctiva and eyelid, associated with inflammation reaction due to adherence of Immunoglobulin E (IgE) to mast cellThe treatment objective for ocular allergy is to minimizee contact with allergen and eye drops (antihistamine, mast cell stabilizer (sodium cromoglycate, pemirolast potassium, lodoxamide, nedocromil sodium), combination of antihistamine and mast cell stabilizer (corticosteroid, cyclosporine). This study was aimed to evaluate the different effect of pemirolast potassium 0,1\% and sodium cromoglycate $4 \%$ in decreasing IgE concenration. A pre and post clinical trial design was performed in 32 patients with ocular allerg divided equaly in two treatment groups. The tears of patients were taken in the first day and one week after treatment to perform IgE concentration, and was evaluated using ELISA reader. The level of IgE concentration before and after treatment in every group was analyzed with paired t-test dependent, and differences between two drugs was compared using unpaired Ttest. In pemirolast potassium 0,1\% group, the initial IgE concentration was 730,73 $\pm 40,17 \mathrm{IU} / \mathrm{ml}$ and decreased into $678,61 \pm 56,20 \mathrm{IU} / \mathrm{ml}$. While the initial IgE concentration of sodium cromoglycate group was $731,16 \pm 32,13 \mathrm{IU} / \mathrm{ml}$ and decreased into $686,73 \pm 43,08 \mathrm{IU} / \mathrm{ml}(p=0,000)$. The difference of decreasing concentration on pemirolast potassium $0,1 \%$ group was $52,12 \pm 41,00 \mathrm{lU} / \mathrm{ml}$ and $44,43 \pm 32,63 \mathrm{lU} / \mathrm{ml}$ on sodium cromoglycate $4 \%$ group. Those differences of decreasing concentration of the two groups were not significant. It can be concluded that there were no differences between pemirolast potassium $0,1 \%$ and sodium cromoglycate $4 \%$ in decreasing the IgE concentration of ocular allergic patients.
\end{abstract}

Keywords: IgE concentration, ocular allergy disease, pemirolast potassium 0,1\%, sodium cromoglycate $4 \%$

Jurnal Kedokteran Brawijaya, Vol. 27, No. 2, Agustus 2012; Korespondensi: Yasmine. Laboratorium Ilmu Kesehatan Mata Rumah Sakit Dr. Saiful Anwar Malang, Jl. Jaksa Agung suprapto No.2 Malang Tel. (0341)366242Email:curl_opth@yahoo.co.id 


\section{PENDAHULUAN}

Penyakit alergi okuli adalah suatu penyakit alergi pada konjungtiva atau kulit kelopak mata yang berhubungan dengan reaksi inflamasi yang timbul akibat respon imun. Reaksi inflamasi pada penyakit alergi okuli ditimbulkan oleh immunoglobulin E (IgE) yang menempel di sel mast dan menyebabkan lepasnya mediator-mediator inflamasi $(1,2)$. Klasifikasi penyakit alergi okuli dibagi berdasarkan gambaran klinisnya, yaitu seasonal allergic conjunctivitis (SAC), perennial allergic conjunctivitis (PAC), atopic keratoconjunctivitis (AKC), vernal keratoconjunctivitis (VKC) dan giant papillary conjunctivitis (GPC) (1-3).

Penyakit alergi okuli merupakan penyakit yang sering dijumpai pada penderita dengan riwayat alergi. Sekitar $32 \%$ dari seluruh anak yang menderita penyakit atau kondisi alergi, manifestasi yang pertama kali timbul adalah penyakit alergi okuli. Prevalensi penyakit alergi okuli sebesar $15-20 \%$ di dunia. Hampir $80 \%$ penderita alergi okuli didapatkan pada usia kurang dari 30 tahun (4).

Immunoglobulin $\mathrm{E}$ berperan sebagai mediator utama antara alergen dengan sel mast pada reaksi hipersensitivitas tipe 1 . Reaksi hipersensitivitas tipe 1 diawali dengan kontak alergen dengan antigen presenting cell (APC). Hal ini menyebabkan sel T helper tipe 2 (Th2) merangsang sel B untuk memproduksi IgE. Pada tahap selanjutnya IgE akan terikat pada permukaan sel mast. Selain itu, sel Th2 juga merangsang aktivasi eosinofil dan menyebabkan lepasnya granul-granul yang akan menyebabkan reaksi alergi fase lambat. Saat terjadi pajanan ulang dengan alergen, alergen akan terikat pada IgE di permukaan sel mast dan menginduksi terjadinya influks kalsium. Influks kalsium akan menyebabkan terjadinya degranulasi sel mast. Degranulasi sel mast mengakibatkan lepasnya mediator-mediator inflamasi sehingga timbul reaksi alergi baik fase cepat (vasodilatasi, spasme otot polos) maupun fase lambat (edema mukosa, sekresi mukus, infiltrasi lekosit, bronkhospasme). Salah satu produk dari degranulasi sel mast adalah interleukin-4 (IL-4). Interleukin-4 akan mengaktivasi kembali sel Th2 sehingga terjadi positive feedback pada proses alergi. Sel Th2 akan mengaktivasi sel B dan merangsang kembali produksi IgE sehingga proses alergi berlangsung terusmenerus. Pengukuran IgE air mata dapat menjadi salah satu hal terpenting untuk mendiagnosa konjungtivitis alergi (6). Penelitian yang dilakukan oleh Nomura dan Takamura menggunakan ELISA, menyebutkan bahwa didapatkan peningkatan kadar IgE air mata pada penderita VKC, SAC dan $\operatorname{PAC}(7,8)$.

Penatalaksanaan penyakit alergi okuli meliputi meminimalkan kontak dengan alergen dan pemberian obat-obatan. Obat-obatan yang digunakan adalah antihistamin, stabilisator sel mast (mast cell stabilizer), kombinasi antihistamin dengan stabilisator sel mast, kortikosteroid, dan siklosporin (9). Stabilisator sel mast merupakan salah satu pilihan terapi utama pada penyakit alergi okuli. Beberapa obat tetes mata yang termasuk dalam golongan stabilisator sel mast yaitu sodium cromoglycate, pemirolast potassium, lodoxamide, dan nedocromil sodium $(9,10)$.

Sodium cromoglycate bekerja dengan cara memblok jalur kalsium pada membran sel mast sehingga mencegah sel mast terdegranulasi dan lepasnya mediator-mediator inflamasi, menghambat aktivasi sel inflamasi yang lain seperti neutrofil, monosit dan eosinofil, memperpanjang tear breakup time pada penderita konjungtivitis kronik. Obat ini efektif pada alergi okuli karena reaksi hipersensitivitas tipe 1 dan juga tersedia dengan harga yang terjangkau oleh semua lapisan masyarakat (11).

Pemirolast potassium 0,1\% merupakan suatu stabilisator sel mast generasi baru yang digunakan sebagai terapi penyakit alergi okuli. Dari penelitian-penelitian terdahulu, dikatakan bahwa pemirolast potassium $0,1 \%$ lebih cepat mengurangi rasa gatal dibandingkan dengan obat anti alergi lainnya, namun obat ini tersedia dengan harga 3 kali lipat dibandingkan sodium cromoglycate 4\% (11). Obat ini bekerja menghambat influx kalsium sehingga menghambat pelepasan mediator inflamasi dari sel mast, menghambat metabolisme phospholipid pada membran sel mast, menghambat antibodi (IgE), menghambat kemotaksis eosinofil dan memblok pelepasan mediator eosinofil $(11,12)$.

Penelitian yang dilakukan oleh Irfani (2008) pada penggunaan pemirolast potassium 0,1\% dengan sodium cromoglycate $4 \%$ pada penderita konjungtivitis vernalis, didapatkan hasil bahwa kedua obat sama efektifnya dalam mengontrol gejala, tanda klinis dan jumlah eosinofil konjungtiva (11). Immunoglobulin $\mathrm{E}$ berperan pada penyakit alergi okuli karena reaksi hipersensitivitas tipe 1. Pada reaksi alergi ini akan terjadi degranulasi sel mast yang menyebabkan lepasnya mediator-mediator inflamasi sehingga timbulah gejala dan tanda alergi okuli. Stabilisator sel mast berperan menghambat terjadinya degranulasi sel mast sehingga menghambat pelepasan mediator-mediator inflamasi, yaitu histamine, IL-4 dan lain-lain. Lepasnya IL-4 dapat merangsang sel B untuk memproduksi IgE dan proses alergi berlangsung terusmenerus. Secara teori berdasarkan mekanisme kerjanya, pemirolast potassium $0,1 \%$ lebih efektif dalam menurunkan konsentrasi IgE daripada sodium cromoglycate $4 \%$.

Penelitian ini dilakukan untuk mengetahui pengaruh pemberian pemirolast potassium $0,1 \%$ dan sodium cromoglycate $4 \%$ terhadap konsentrasi IgE air mata penderita alergi okuli. Penelitian ini diharapkan dapat menjadi dasar dalam pemilihan terapi untuk penderita alergi okuli.

\section{METODE}

Penelitian dilakukan dengan desain pre and post clinical trial pada 32 penderita alergi okuli yang dibagi menjadi dua kelompok perlakuan, yaitu 16 penderita yang mendapatkan tetes mata pemirolast potassium 0,1\% (Alegysal) dan 16 penderita yang mendapatkan tetes mata sodium cromoglycate $4 \%$ (Conver $4 \%$ ). Subjek penelitian berasal dari pasien poli Pediatrik Oftalmologi dan InfeksiImunologi yang didiagnosa alergi okuli. Data karakteristik pasien yang diambil adalah usia, jenis kelamin (sex) dan riwayat alergi. Diagnosa alergi okuli ditegakkan berdasarkan keluhan utama, anamnesa dan pemeriksaan klinis. Air mata penderita diambil dua kali untuk dilakukan pemeriksaan kadar IgE, yaitu saat datang dan satu minggu setelah terapi. Konsentrasi IgE diperiksa menggunakan ELISA reader dengan panjang gelombang $450 \mathrm{~nm}$. Penelitian ini berjalan selama 2 bulan karena air mata penderita hanya bertahan selama 2 bulan didalam freezer dengan suhu $-80^{\circ} \mathrm{C}$. Air mata yang disimpan dalam freezer dengan suhu $-80^{\circ} \mathrm{C}$ dan lebih dari 2 bulan akan mengalami 
denaturasi dari protein air mata dan dapat mengganggu hasil penelitian. Pemeriksaan konsentrasi IgE air matanya menggunakan ELISA reader dengan panjang gelombang $450 \mathrm{~nm}$ hanya dapat dilakukan 1 kali untuk semua sampel air mata karena reagen yang digunakan hanya dapat dipakai 1 kali setelah dibuka segelnya sehingga sampel dikumpulkan dan diperiksa secara bersamaan (13).

Penurunan konsentrasi IgE air mata sebelum dan setelah terapi pada masing-masing obat tetes mata diuji menggunakan uji paired $T$-test, sedangkan perbandingan penurunan konsentrasi IgE air mata antara kedua obat tetes mata diuji menggunakan uji unpaired $T$-test dengan menggunakan software SPSS release 15.

\section{HASIL}

Hasil uji beda pada dua kelompok perlakuan menunjukkan bahwa dari segi karakteristik usia, jenis kelamin dan riwayat alergi, pasien yang diambil untuk kedua kelompok tidak ada perbedaan signifikan.

Tabel 1. Karakteristik sampel pada kelompok Pemirolast potassium $0,1 \%$ dan Sodium cromoglycate $4 \%$

\begin{tabular}{lccccc}
\hline $\begin{array}{l}\text { Karakteristik } \\
\text { Demografi }\end{array}$ & $\begin{array}{c}\text { Pemirolast } \\
\mathbf{0 , 1 \%}(\mathbf{n}, \%)\end{array}$ & potassium & $\begin{array}{c}\text { Sodium } \\
\mathbf{4} \%(\mathbf{n} \%)\end{array}$ & cromoglycate & $\boldsymbol{p}$-value \\
\hline Usia & $9,13 \pm$ SD 3,32 & & $8.69 \pm$ SD 1,25 & & 0,626 \\
Jenis kelamin (sex): & 13 & $40,6 \%$ & 11 & $34,4 \%$ & 0,564 \\
Laki-laki & 3 & $9,4 \%$ & 5 & $15,6 \%$ & \\
Perempuan & & & & & \\
Riwayat alergi pasien: & 5 & $15,6 \%$ & 6 & $18,8 \%$ & 0,780 \\
$(-)$ & 11 & $34,4 \%$ & 10 & $31,3 \%$ & \\
$(+)$ & & & &
\end{tabular}

${ }^{*}$-value $<0,05$ bermakna secara statistik

Hasil uji paired sample t test untuk perbandingan antara konsentrasi IgE (IU/mL) sesudah terapi pada kedua kelompok lebih rendah secara signifikansi $(p=0,000)$ bila dibandingkan sebelum terapi

Tabel 2. Hasil perbandingan antara konsentrasi IgE (IU/mL) pada saat pre terapi dan post terapi

\begin{tabular}{|c|c|c|c|c|c|}
\hline & \multicolumn{4}{|c|}{ Evaluasi } & \multirow{3}{*}{$p$} \\
\hline & \multicolumn{2}{|c|}{ Pre terapi } & \multicolumn{2}{|c|}{ Post terapi } & \\
\hline & Mean & \pm SD & Mean & \pm SD & \\
\hline Pemirolast potassium $0,1 \%$ & 730,73 & 40,17 & 678,61 & 56,20 & 0,000 \\
\hline Sodium cromoglycate $4 \%$ & 731,16 & 32,13 & 686,73 & 43,08 & 0,000 \\
\hline
\end{tabular}

Uji lanjut dengan $t$ dependet pada penurunan konsentrasi IgE menunjukkan bahwa konsentrasi IgE sebelum terapi lebih tinggi daripada setelah terapi. Pada kelompok dengan pemberian pemirolast potassium 0,1\% terjadi penurunan konsentrasi IgE sebesar $52,12 \mathrm{IU} / \mathrm{ml}$ $(S D=41,00)$ sedangkan pada pemberian sodium cromoglycate sebesar $44,43 \mathrm{IU} / \mathrm{ml}(\mathrm{SD}=32,36)$. Hasil uji $\mathrm{t}$ independent menunjukkan tidak ada perbedaan signifikan penurunan konsentrasi IgE sesudah terapi antar pemberian pemirolast potasium $0,1 \%$ dan sodium cromoglycate $4 \%(p=0,561)$.

\section{DISKUSI}

Sampel yang mengikuti penelitian ini adalah penderita berusia 6-30 tahun, baik laki-laki atau perempuan yang didiagnosa sebagai alergi okuli. Pada literatur dikatakan bahwa hampir $80 \%$ penderita alergi okuli pada usia kurang dari 30 tahun. Di Negara Jepang, dilaporkan bahwa 12,2\% penderita alergi okuli adalah anak-anak dan penderita alergi okuli dewasa sebesar $14,8 \%$. Penelitian di Swedia menyatakan bahwa prevalensi penderita alergi okuli adalah sebesar $19 \%$ pada anak-anak usia 12-13 tahun. Baig dkk (2010) di Karachi melaporkan bahwa penderita alergi okuli adalah 19,2\% pada anak-anak usia 5-19 tahun. Penyakit alergi okuli ini menurun seiring dengan pertambahan usia, dimana kasus alergi okuli jarang didapatkan pada penderita usia tua (usia 60 tahun atau lebih). Hal ini disebabkan oleh penurunan fungsi sel $\mathrm{T}$ karena pertambahan usia. Penurunan fungsi sel T mengakibatkan disregulasi fungsi sel $B$ dan menyebabkan penurunan produksi IgE $(4,14)$.

Sel T merupakan sel limfosit yang berperan pada sistem imun spesifik selular. Secara spesifik, yang berperan pada imunitas selular adalah sel T CD4 ${ }^{+}$. Pada penderita usia tua, didapatkan jumlah sel $\mathrm{T} \mathrm{CD}^{+} \mathrm{CD}^{2} 5 \mathrm{RO}^{+}$"memoryphenotype" yang berlebihan dan sedikit jumlah sel T CD4 $4^{+}$ $\mathrm{CD} 4 \mathrm{RA}^{+}$naïve-phenotype pada sel mononuklear darah tepi. Akumulasi sel memori sel $\mathrm{T} \mathrm{CD4}^{+} \mathrm{CD}_{45 \mathrm{RO}^{+}}$ mengakibatkan penurunan kemampuan berespon terhadap antigen baru dan antigen lama. Sehingga kasus aiergi okuli jarang didapatkan pada penderita usia tua (usia 60 tahun atau lebih) (15).

Pada sebaran data jenis kelamin didapatkan bahwa penderita laki-laki lebih banyak daripada perempuan pada kedua kelompok. Belum didapatkan literatur yang secara spesifik menyebutkan bahwa didapatkan lebih banyak penderita laki-laki pada alergi okuli secara umum. Biasanya penderita laki-laki lebih banyak didapatkan pada vernal keratoconjunctivitis (VKC). Sedangkan pada jenis alergi okuli yang lain, yaitu SAC, PAC, AKC dan GPC didapatkan bahwa penderita laki-laki dan perempuan memiliki rasio yang sama (2).

Sebaran data penderita dengan riwayat alergi pada kedua kelompok dilaporkan bahwa lebih dari $50 \%$ penderita memiliki riwayat alergi. Pada literatur dikatakan bahwa sekitar $50 \%$ penderita alergi okuli memiliki riwayat alergi (atopi). Atopi adalah respon sistem imun humoral terhadap allergen yang melibatkan produksi allergenspecific IgE. Penderita dengan riwayat alergi (atopi) lebih mudah terjadi alergi okuli. Hal ini disebabkan oleh adanya riwayat pajanan awal terhadap antigen spesifik sehingga merangsang produksi IgE. IgE yang diproduksi menempel pada reseptornya di permukaan sel mast. Pajanan ulang menyebabkan antigen menempel pada IgE di sel mast dan terjadilah degranulasi sel mast. Pada saat terjadi pajanan ulang inilah konsentrasi IgE dapat meningkat sampai 10 kali dari konsentrasi IgE normal (3).

Konsentrasi IgE normal orang dewasa sebesar $120 \mathrm{IU} / \mathrm{ml}$. Rata-rata konsentrasi IgE normal adalah antara 4,2 sampai $592 \mathrm{IU} / \mathrm{ml}$. Pada penderita dengan riwayat alergi, konsentrasi IgE dapat meningkat sampai 10 kali dari konsentrasi IgE normal. Penurunan konsentrasi IgE pada 
kedua kelompok disebabkan oleh adanya pengikatan IgE oleh pemirolast potassium $0,1 \%$ sehingga IgE tidak berikatan dengan antigen dan sel mast, hambatan terhadap influks kalsium ke dalam membran sel mast, pengikatan antigen sehingga tidak terjadi ikatan dengan IgE di membran sel mast, dan hambatan terhadap aktivasi eosinofil. Hal-hal ini dapat mencegah terjadinya degranulasi sel mast sehingga dapat mengurangi lepasnya histamin dan mediator-mediator inflamasi yang lain (3).

Sodium cromoglycate $4 \%$ bekerja dengan cara menghambat influks kalsium ke dalam membran sel mast dan menghambat aktivasi eosinofil. Hambatan terhadap influks kalsium menyebabkan terhambatnya degranulasi sel mast. Sel mast yang terdegranulasi akan menghasilkan mediator-mediator inflamasi, selain itu juga akan merangsang sel Th2 dengan perantara IL-4. Sel Th2 akan merangsang sel B untuk memproduksi IgE. Secara tidak langsung, sodium cromoglycate menghambat produksi IgE berikutnya (16).

\section{DAFTAR PUSTAKA}

1. Bielory L and Friedlaender MH. Allergic Conjunctivitis. Immunology and Allergy Clinics of North America. 2008; 28(1): 43-58.

2. Del Cuvillo A, Sastre J, Montoro J, et al. Allergic Conjunctivitis and $\mathrm{H} 1$ Antihistamines. Journal of Investigational Allergology and Clinical Immunology. 2009; 19(1): 11-18.

3. Amod R. Immunology of Allergic Eye Disease. Current Allergy \& Clinical Immunology. 2006; 19: 70-73.

4. Bonini S, Sgrulletta R, Coassin M, and Bonini S. Allergic Conjunctivitis: Update on Its Pathophysiology and Perspectives for Future Treatment. In: Pawankar R (Ed). Allergy Frontiers: Clinical Manifestations. Rome: Springer; 2009; p. 25-48.

5. Kumar V, Abbas A, and Fausto N. Diseases of Immunity. In: Kumar V (Ed). Pathologic Basis of Veterinary Disease 7th edition. Philadelphia: Elsevier Saunders; 2005; p. 194-208.

6. Mahran M, Hagag M, and Shouman A. Involvement of Interleukin-16 (IL-16) in Allergic Conjunctivitis. Australian Journal of Basic and Applied Sciences. 2009; 3(4): 3266-3272.

7. Nomura K and Takamura E. Tear IgE Concentrations in Allergic Conjunctivitis. Eye. 1998; 12(2): 296-298.

8. Pokharel S, Hah DN, Joshi SN, and Choudhary M. Tearfilm Immunoglobulin E (IgE) Level in Vernal Keratoconjunctivitis by ELIS. Kathmandu University Medical Journal. 2009; 7(26): 104-108.

9. Moloney G and McCluskey PJ. Classifying and Managing Allergic Conjunctivitis. MedicineToday. 2007; 8(11): 16-21.

10. Manzouri B, Flynn T, and Ono SJ. Allergic Eye Disease: Pathophysiology, Clinical Manifestation and Treatment. In: Reinhard T (Ed). Cornea and External
Pemirolast potassium 0,1\% berefek terhadap IgE baik secara langsung maupun secara tidak langsung sehingga penurunan konsentrasi IgE post terapi lebih besar bila dibandingkan dengan sodium cromoglycate $4 \%$. Hal ini mungkin disebabkan oleh kerja pemirolast potassium $0,1 \%$ yang secara langsung menghambat IgE menempel pada sel mast dan menghambat antigen menempel pada IgE di sel mast sehingga mencegah terjadinya degranulasi sel mast. Hambatan terhadap degranulasi sel mast juga akan menghambat produksi IgE secara tidak langsung. Sodium cromoglycate $4 \%$ menghambat degranulasi sel mast sehingga secara tidak langsung menghambat produksi IgE berikutnya (17).

Dari hasil penelitian ini dapat disimpulkan bahwa pemirolast potassium $0,1 \%$ dan sodium cromoglycate $4 \%$ tetes mata memiliki efek dalam penurunan konsentrasi IgE penderita alergi okuli. Tidak didapatkan perbedaan antara pemirolast potassium 0,1\% dan sodium cromoglycate 4\% dalam menurunkan konsentrasi IgE air mata pada penderita alergi okuli.

Eye Disease. Heidelberg: Springer; 2006; p. 209-222.

11. Irfani I. Perbandingan Efektivitas Tetes Mata Natrium Kromoglikat 4\% dengan Kalium Pemirolast 0,1\% pada Pengobatan Konjungtivitis Vernalis. Majalah Kedokteran Bandung. 2008; 40(4): 187-192.

12. David G and Shulman MD. Two Mast Cell Stabilizers, Pemirolast Potassium 0,1\% and Nedocromil Sodium $2 \%$, in the Treatment of Seasonal Allergic Conjunctivitis: A Comparative Study. Advances in Therapy. 2003; 20(1): 31-40.

13. Inada N, Soji J, Kato H, Kiely S, Mulyanto, and Sawa M. Clinical Evaluation of Total IgE in Tears of Patients with Allergic Conjunctivitis Disease Using a Novel Application of the Immunochromatography Method. Allergology International. 2009; 58(4): 585-589.

14. Mediaty A and Neuber K. Total and Specific Serum Ige Decreases with Age in Patients with Allergic Rhinitis, Asthma and Insect Allergy but Not in Patients with Atopic Dermatitis. Immunity and Ageing. 2005; 2(9): 16.

15. Anupama N, Sharma MV, Nagaraja HS, and Bhat MR. The Serum Immunoglobulin $E$ Level Reflects the Severity of Bronchial Asthma. Thai Journal of Physiological Sciences. 2006; 18(3): 35-40.

16. Kemp SF. Cromolyn and Nedocromil: Nonsteroidal Anti-Inflammatory Therapy for Asthma and Other Allergic Diseases. In: Lieberman P (Ed). Allergic Disease, Diagnosis and Treatment 3rd edition. New York: Humana Press; 2007; p. 367-377.

17. Gous P, and Ropo A. A Comparative Trial of the Safety and Efficacy of 0.1 Percent Pemirolast Potassium Ophthalmic Solution Dosed Twice or Four Times a Day in Patients with Seasonal Allergic Conjunctivitis. Journal of Ocular Pharmacology and Therapeutics. 2004; 20(2): 139-150. 